\title{
IMPLEMENTING \\ A QUALITY MANAGEMENT SYSTEM IN THE CROATIAN PUBLIC ADMINISTRATION
}

\begin{abstract}
Purpose: On the example of a regional self-government unit, the paper aims to provide additional evidence to support the notion that the application of a quality management system (QMS) in public administration produces positive change in organizational culture, improves business processes as well as the quality and delivery of services, etc., and, as such, is a necessary precondition for modernization and improvement of its efficiency.
\end{abstract}

Methodology: International scientific and professional research shows that the application of quality management systems in public administration is a prerequisite for modernization and improvement of overall system efficiency. The paper gives an overview of the QMS implementation in public administration in the Republic of Croatia and presents the effects of the application of the international standard ISO 9001 in Osijek-Baranya County.

Results: The results indicate that the application of QMS in Osijek-Baranya County has had significant effects on the operation of public administration. The most significant among them are financial savings, increased transparency, acceleration of business processes, etc.

Conclusion: The application of a quality management system in public administration has produced positive effects especially in terms of improving (streamlining and speeding up the processes as well as increasing transparency of work thus providing an avenue towards modernizing and improving the overall efficiency of public administration.

Keywords: Quality management system (QMS), public administration, ISO 9001

\section{Introduction}

Due to its role and importance in society, public administration has come under growing pressure to meet the expectations of citizens and respond to their demands for higher quality of services and service delivery. Existing professional and scientific research provides an insight into the work of public administration and, through critical thinking, seeks to identify new ways of increasing its quality.

A quality management system is often associated with the efficiency of public administration i.e., identified as a tool for enhancing its efficiency, orga- 
nizing and improving processes, increasing transparency, etc.

"A low level of knowledge and awareness of the benefits brought by management in organizations is one of the main causes of the low level of implementation of management systems in organizations in the Republic of Croatia. A lack of standardized management systems, which include tools for risk assessment and risk minimization and various other requirements of internationally recognized management system standards, can significantly affect the operations and life cycle of organizations, regardless of their size, organizational structure and type of ownership" (Britvic, 2011).

The aim of this paper is to answer the following research questions: Can quality management systems improve the quality of public administration, and if so, in which areas will these improvements be most visible? To do this, a review was conducted first of available scientific and professional literature in this field. Next, the status of implementation of quality management systems in public administration bodies in the Republic of Croatia has been analyzed and it was found that a significant number of them have not yet implemented a quality management system. The third part of the paper analyzes and presents the positive effects of QMS implementation on the example of Osijek-Baranya County, thus providing further evidence in support of the implementation of QMS in public administration.

\section{Literature Review}

Historical records show that Hammurabi, the king of Babylonia, was the first who attempted to bring order and structure to the operation of his entrepreneurs by passing the famous Hammurabi Code, striving to protect customers and discourage small business fraudsters (Petar, 1996). Even in those ancient times there was an awareness was developed of the quality and protection of service users as a priority of the precursor of today's public administration. The quality of public administration is an issue the scientific and professional communities had been seeking to shed light on for some time. In the 1990s, the implementation of quality management systems in the public sector reached unprecedented proportions. The implementation was part of ambitious public administration reengineering efforts, but just like with most programs implemented in public service, it was examined first if they justify the investments. Since most benefits are difficult to measure and often depend on the implementation, it is not always easy to document the impact of such systems. Given the importance of public services and the fact that it involves the spending of public money, this topic has become popular among researchers. There is a need for a new approach to services in public administration. Changes in public administration affect both public service understanding and delivery. In order to achieve citizen/customer satisfaction in terms of efficiency and quality, current practices are questioned and improvements are sought. A constant increase in the number of laws and regulations entails high costs and creates customer dissatisfaction with state administration services. In this context, quality management systems are needed (Sisek \& Pavković, 2008). By analyzing the institutional conditions needed for improvement of economic well-being of counties, Biškup (2012) claims that a large number of studies on the functioning of institutional support indicate the weaknesses and underdevelopment of many elements of the business environment, which act as limiting factors for entrepreneurial activities and faster economic growth. The monopolistic role of local government units imposes the need for protection of public service users. Fazlović and Kakeš conducted secondary research into the satisfaction of public service users in Bosnia and Herzegovina and conducted a survey to measure the management and employee attitudes toward QMS. Their study found that the implementation of a quality management system improves the quality of services provided by the public sector (Fazlović \& Kakeš, 2015).

The main purpose of the Common Assessment Framework (CAF) model is to provide a simple, free and easy-to-use framework for self-assessment of the public sector in Europe, with the aim of sharing experiences and good practices, and benchmarking activities. This "diagnostic" tool provides a clearer understanding of the institution applying it to its current position, as well as the goals and results it plans to achieve, together with guidelines on how to do that (Engel, 2002).

In his study of work standardization in local selfgovernment units, Vujić (2018) notes that the main role of local self-government is to provide quality services to citizens and other service users. By applying the quality management system ISO 9001 and BFC SEE, the needs and expectations are met 
of the partners of local self-government, i.e., citizens, employees, businesses, and suppliers. The implementation of a quality management system not only improves the quality of public services, accelerates handling of requests, enhances access to information transparency and adherence to the principles of legality, but also meets a whole range of other needs thus improving citizens' quality of life and the well-being of society as a whole (Jašarević \& Miličević, 2016). The implementation of the quality management system directly affects organizational culture and increases the quality of public administration to meet the criteria for the accession of Bosnia and Herzegovina to the European Union. The authors conducted a survey among employees of five municipalities of Zenica-Doboj Canton to investigate the influence of organizational culture on the application of quality management systems. The results show a high level of correlation between municipalities that have implemented a quality management system and a trend towards improving service quality. The research points to the need to implement a quality management system as a tool for improving management practices in Bosnia and Herzegovina and bring them closer to European standards (Jarčević \& Miličević, 2016).

On the example of the municipality of Vulcana-Bai, Matei and Bălăceanu (2014) analyze the application of quality management systems in relation to self-assessment. A successful development strategy involves monitoring performance. Effective application of the self-assessment system requires an integrated process management system, the use of appropriate methodology and systematic analyses. The authors' recommendations include using indicators to evaluate the satisfaction of employees and tailoring them to the users (employees, citizens, etc.) to reflect the reality of the institution. Džinić and Manojlović (2016) analyzed the impact of the application of ISO standards, quality awards and customer satisfaction surveys on organizational efficiency on the example of the City of Pula local government. The research showed a positive correlation between the application of ISO standards, quality awards and organizational efficiency, but not with service user satisfaction surveys. Paljaga (2001) analyzes the introduction of total quality management in local government units. By using the example of the City of Rovinj, he describes the process of implementing the international quality management system ISO 9000, points out the chal- lenges faced during the implementation, the impact on the organization, organizational changes, as well as changes in the culture of public administration that will lead to improved satisfaction of customers, i.e. taxpayers. The system requires sustained efforts in identifying better technical, technological, and marketing tools with the aim of improving service quality and delivery. Williams et al. (2006) review academic and practical validity of the model of excellence with particular emphasis on Malcolm Baldrige and the European Model of Excellence using available scientific papers and own experience gained through research. They conclude that models of excellence are good for institutions that plan to apply them, while institutions that are in the process of applying them should adjust them to their own needs, i.e., developing their own business models and strategies in the long run. After five years of application, Staes and Thijs (2005) report on the effects of CAF implementation after stating that the public sector faces numerous challenges and has to respond to many new needs, expectations and demands of service users and the environment. Challenges drive reforms, and the pace of public administration reform has been much faster in the last two decades than before. Increasing change requires new methods and techniques that promote efficiency and transparency, and are based on the principles of good governance. Techniques such as ' management by objectives', 'cost-benefit analysis', 'market testing', and 'performance related pay' have been introduced.

As public administration itself is a highly standardized system, the question arises as to the justification for implementing a quality management system and the applicability of the ISO 9001 standard in the context of public administration since initially it used to be a technical standard. Analyses were based on motivation, the registration process, difficulties and derived benefits (Singh \& Mansour-Nahra, 2006). The authors suggested that the implementation brought about meaningful benefits. One of the largest surveys was conducted by a group of authors (Fonseca et al., 2019), whose aim was to identify obstacles, benefits, leading practices and lessons learned in the transition/ certification of the revised standard of the quality management system ISO 9001:2015. Surveys were conducted in Portugal, Romania, Switzerland and Turkey of organizations from various sectors and of various sizes. The results show that the perceived 
benefits of using ISO 9001:2015 in an organization include tangible results such as cost savings and higher customer satisfaction. Another survey compared knowledge management, customer satisfaction and organizational image in certified and non-certified (ISO 9001) municipalities. Out of 81 municipalities surveyed, 40 were certified and 41 were not. The authors concluded that in comparison with non-certified municipalities, certified municipalities had achieved better results in terms of competitive orientation and customer satisfaction (Brito \& Figueiredo, 2020). The importance of quality certification for both employees and residents is highlighted. Ćwiklicki et al. (2019) have identified and assessed the development of ISO 9001 Quality Management System applications in Polish local government institutions in the 1999-2015 period. The analysis was conducted on the basis of a questionnaire survey carried out among local government institutions in 2015 (with a response rate of 77\%). The ISO 9001 Quality Management System is dominant in Polish local government institutions. The results show that the implementation of the system was geographically concentrated and dependent on the size of the local government institution. The main reason for implementing and obtaining a certification lies in management improvement. Nurcahyo et al. (2019) measured the efficiency of the ISO 9001-certified public healthcare centers in Jakarta, Indonesia, and examined the impact of "re-certification" on its efficiency. The survey sample comprised 30 ISO 9001-certified district public healthcare centers, only $23 \%$ of which can be categorized as technically efficient. This research found that there are no significant differences in efficiency among the groups of public healthcare centers based on the number of "re-certifications" of the respective centers. The authors conclude that ISO 9001 registration does not guarantee higher efficiency; however, management should ensure that the ISO 9001 implementation method used by the healthcare center is appropriate for improving the efficiency of such centers. Marimon et al. (2019) examined the impact of motivations on the benefits of quality management systems in social services. They report that, although many social service organizations are implementing quality management systems, little is known about the benefits of such systems, as well as factors that influence them. They conducted a survey of 196 European social service organizations and analyzed the data collected using the factor analysis. The results confirmed that the benefits are multidimensional consisting of society, customer, operational, employee, and economic domains. Furthermore, Kozhevina et al. (2015) suggest that the advantages of the implementation of a quality management system in the public sector could be grouped into at least four major benefits. One of them is a systematic approach to the evaluation of operations of both organizations and their managers. The second one is the fact that qualitative values obtained enable more justified decisionmaking related to the development of organizations. The last two are assistance in achieving social goals and prompt identification of gaps in terms of public sector organization manager competencies. The quality management system is considered a tool for combating corruption. The authors developed a model based on the quality management system similar to the general total quality system based on ISO 9001. The implementation benefits could be seen in the comparison of current values and planned values. The results of the analysis based on monitoring customer satisfaction and the results provided in internal audits could point to the existing trends. They could be used to improve the decision-making process and plan and implement corrective actions. Improvements are significant and evident in the increase in the amount of communicated information, improvements in internal regulatory documentation and more severe penalties, which would in turn result in a quality system implemented that has a favorable impact on the competitiveness of the domestic economy and welfare of the citizens (Ivanova \& Androsenko, 2014). The total quality system is a necessity in public service since governments have to deal with reduced budgets and the citizens' growing demand for services. If they raise their revenues or if they lower the service quality, politicians might be punished by the voters. By exploring the case of the Japan International Cooperation Agency as public service in Bangladesh, Tachiki (2010) concludes that total quality management eliminates waste and inefficiencies. Successful implementation of a quality management system requires a systematic approach and generally brings improvements. One of the most important benefits is a service that better matches customers' needs (Selen \& Schepers, 2001). The use of total quality management involves several major problems, such as insufficient modification of services, insensitivity to the problems of defining government customers, an inappropriate emphasis on inputs and processes, and demands 
for top-level leadership that can rarely be met by governmental culture. Total Quality Management (TQM) was originally designed for routine processes such as manufacturing, yet most government agencies produce services rather than products (Douglas, 2018). Additionally, Mani (1995) explores if there are improvements after the implementation of a quality management system in the government agency Internal Revenue Service (IRS). The quality management system was implemented as a solution to the problem of services with which customers were not satisfied. The implementation process was burdened with employee resistance and ideas that "it is inappropriate", "it's just another trend" and "it makes no difference since quality has always been their main objective" (Mani, 1995). In support of Mani's research, Hur (2009) studied the influence of a quality management system on how organizations work and the differences between TQM participants and non-participants. The survey confirmed that despite skepticism among employees at the beginning of the implementation, their attitudes and beliefs changed during the process.

Although the implementation of total quality management is a necessity and public service organizations should strive to implement it, the absence of its success lies in the unwillingness to change. However, major problems in public sector inefficiencies are strong bureaucracy, corruption, government arbitrariness and delay in the proceedings, and total quality management is part of a solution to these problems (Moustakis, 2014). Major disadvantages are associated with not only the costs of ISO implementation, but also the lack of free advice, sometimes the lack of consistency between auditors, and the costs associated with its implementation and maintenance (Van den Berghe, 1997). Quality systems are necessary to achieve successful and competitive public service, but in order to make it more efficient, management culture has to be changed. Before implementation, the following needs to be done: adopt TQM as a desired management tool, review regulations and laws on public management, adopt governance principles in public institutions, organize service training using a holistic approach, etc. (Karasoy, 2018).

Quality management systems are seen as a key strategy for organizations to overcome challenges and provide tools, techniques, and methods for continuous process improvement. The implementation results are as follows: organizations improve processes, lower costs, and eliminate unnecessary expenses and all non-value added activities (PerisOrtiz et al., 2015).

The research presented in the scientific and professional literature clearly shows that quality management systems contribute to the quality of public administration services. The successful operation of the system depends largely on the commitment of all levels of management to quality management according to principles that significantly go beyond the "standardized" and "well-established" frameworks and indicate significant changes in organizational culture. Customer satisfaction in the widest possible sense is the cornerstone of quality management. Quality enhancing tools are quality management systems, reward systems, and customer service satisfaction measurement. The success of the system depends on the quality of employees, and the experience gained in Western Europe indicates that quality is achieved through lifelong learning. At the same time, once implemented, quality management systems require constant adaptation. For a system to be successful, assessments must be made that take into account the specificities of the institution in which they are implemented, and that use the criteria and parameters that best fit the fundamental purpose of that institution. The preconditions for public administration reforms are clearly defined legislation and strategy.

\section{Overview of quality management systems used in the public sector in the Republic of Croatia}

Despite the fact that the scientific and professional public have identified different quality management systems, complete official statistics on their application in public administration in the Republic of Croatia are not available. Thus, for the purpose of this paper, a review of available ISO quality management system websites and the Common Assessment Framework (CAF) was conducted as the most common system used in public administration. Some other elements of quality management tools suggested in the extant literature, such as a reward system, are considered a segment of the quality management tool, and because of that, there were no further analyses thereof.

CAF was developed as a result of the cooperation among the EU Ministers responsible for Public Administration. It was presented in May 2000 and has been revised several times so far. A CAF Resource Centre (CAF RC) was created at the European Insti- 
tute of Public Administration (EIPA) in Maastricht following the decision of the Directors General in charge of public service. It works in close cooperation with the network of CAF national correspondents. ${ }^{1}$ Although they have a database of registered users, there are no data for Croatia since the Ministry of Public Administration in Croatia has just started with the implementation process.

The International Organization for Standardization (ISO) is an international standard-setting body composed of representatives of various national standardization bodies (164 national standards bodies). It is one of the most renowned international quality organizations. ${ }^{2}$ Its members systematically monitor the number of certificates by sector and by country. ${ }^{3}$ The analysis covers 195 countries and 12 ISO certificates. An overview of certificates used in the public sector shows that ISO 9001, ISO 14001 and ISO/IEC 27001 are mostly implemented and analyzed. ISO 9001 is an international standard for a quality management system (QMS), the ISO 14001 is a standard called Environmental Management Systems, and ISO/IEC 27001 is an information security standard. The table below shows the statistics on ISO certification in the public service sector in Croatia.
The data in the table show a significant decrease in the number of ISO 9001 certificates in 2012 compared to 2009, which slightly grew in 2015, and then again slightly decreased in 2018 . This might suggest that ISO norm revisions were intended to be more user friendly and to include lower requirements in terms of documentation needed. Furthermore, some organizations could have implemented the system without further certifications.

ISO 14001 and ISO/IEC 27001 are not that significant since there are only between 0 and 2 public organizations holding these certificates. The reasons for this trend lie in the scope of certificates. ISO 9001 is a general standard for a quality management system that could be implemented in all organizations, and it could be defined as an overall solution to quality problems in the public sector. In comparison, ISO 14001 and ISO/IEC 27001 each have a different scope, i.e., they refer to a specific part of public responsibilities. Although they complement ISO 9001, their scope is generally regulated by laws.

The chapter below gives an overview of the benefits of implementing a quality management system in Osijek-Baranya County as a regional self-government unit.

Table 1 Number of ISO certificates in the public sector in Croatia

\begin{tabular}{|l|c|c|c|}
\hline YEAR & ISO 9001:2008/2015 & ISO 14001 & ISO/IEC 27001 \\
\hline 2009 & 45 & 2 & 1 \\
\hline 2012 & 21 & 1 & 2 \\
\hline 2015 & 29 & 0 & 0 \\
\hline 2018 & 26 & 1 & 1 \\
\hline
\end{tabular}

Source: Author's own research, according to the information available on the official ISO website

\section{Benefits of the implementation of the ISO 9001 quality management system on the example of Osijek-Baranya County}

Although a quality management system in OsijekBaranya County was planned to be implemented in 2005, it was implemented and certified only in 2011. Malenica et al. (2016) gave an overview of this process in Croatian counties, including Osijek-Baranya County: "International standards ISO 9001:2000

\footnotetext{
https://www.eipa.eu/portfolio/european-caf-resource-centre/

2 https://www.iso.org/about-us.html

3 https://isotc.iso.org/livelink/livelink?func=II\&objld $=18808772$ \&objAction=browse\&viewType $=1$
}

and ISO 9001:2008 required from the regional authorities implementing the system to prepare certain documents within their business systems, which did not pose a problem in terms of their scope of work. However, in business practice this led to unnecessary duplication of documents, as they were already required to produce them by laws, regulations and internal policies." It is important to emphasize that this is a question of voluntary leadership (of the County or County Assembly). In addition, a growing interest in the implementation of QMS in public administration as a means of improving their quality shows that leaders recognize the need for changes and modernization of the system. 
At the same time, the decision made by regional self-governments to maintain QMS despite the fact that this requires time, effort and financial resources, indicates that the implementation has produced the desired results or that the management considers them to be effective and justified.

To evaluate the efficiency of a QMS, an assessment needs to be made of current management practices. Based on this assessment, the methodology for monitoring system efficiency in Osijek- Baranya County was developed. The prefect evaluates system performance annually. The management assessment of the QMS performance is based on an analysis that includes information on the current state and functioning of the system and an assessment of the application of the adopted documents that refer to the system.

The following documents are obtained and examined during the analysis preparation process: reports from the heads of county administrative bodies on the functioning of the administrative body in accordance with the quality system documents and the evaluation of products and services provided by the relevant administrative body with a proposal for improvements, conclusions of the County Assembly containing an assessment of the performance of prefects and governing bodies and the way a particular product and service is provided, a report of the employee responsible for the issues concerning access to information and the right of access to information, reports from the governing bodies and the County Prefect Cabinet on the submitted complaints and proposals of citizens or product and service users, a report of the Office of the State Auditor, a report of the Internal Audit Unit and the persons involved in the internal financial control system, and internal audit reports.

Based on the analysis presented in the report, the prefect evaluates the performance by considering the following elements: the volume of work performed relative to the average possible, execution time relative to the average required (timeliness), compliance with regulations, general and other acts of competent authorities and planning documents (regulatory compliance), compliance with the documents of the quality management system, conditions of realization, the excellence of the work performed, which involves expertise, inventiveness and innovation in preparation and execution, initiative in proposing measures, activities and solutions that enhance the activity, how the work performed contributes to the functions of the body or the County as a whole, customer satisfaction, and other elements relevant to the assessment.

The ISO quality system was implemented in 2011. Although the process started when ISO 9001:2000 was in force, the implementation finished with the ISO 9001:2008 system. One of the most important self-assessment tools was management rating. Because of that, management ratings were analyzed for the years 2013, 2015 and 2017. Major benefits of system implementation are listed below.

The reports underpinning the system evaluation showed the following:

- In 2011, the conditions for taking over the collection of taxes were fulfilled, and the County began with the process of rational management of financial resources. This procedure increased tax collection, and by the end of 2013, enforcement and collection of outstanding tax debt was initiated. By 2017, the outstanding tax debt was fully collected.

- By depositing the funds currently available in the account during the analyzed period, the costs of the received loans and capital projects, which Osijek-Baranya County is in charge of, were fully paid.

- Transparent behavior of County bodies is also evident from the results of survey and evaluations of relevant bodies of the Institute of Public Finance in the analysis of the Openness of the 2016 Budget, which put Osijek-Baranya County among the highestranking counties in Croatia in terms of transparency of their work.

- Creating applications for a range of services that facilitate communication with customers and contribute to transparency made them easier to use, reduced the time spent on proceedings and demonstrated a desire, willingness and ability of self-government to use the latest technology to maintain communication with service users. As of 2011, taxpayers can obtain tax rulings for the current year through their OIB (personal identification number), and check their debt status online, i.e., through the County website. In 2012, the requirements for legalizing illegally constructed buildings were made avail- 
able to service users. In 2013, the requirements with regard to documents needed for procurement of goods and services with an estimated value of up to HRK 200,000 and works with an estimated value of up to HRK 500,000 were made available for downloading from the official website.

- Significant savings were recorded ranging from HRK 10,302,617.92 in 2013 to HRK 1,063,569.12 in 2017.

- Systematic investment in employee training and skills development improved the quality of services provided, with no complaints recorded about the procedures performed.

- The benefits of QMS can also be seen by comparing the administrative bodies of Osijek-Baranya County and their operation with their counterparts in other counties. As of 31 December 2017, Osijek-Baranya County ranked second in terms of the number of requests to legalize illegally constructed buildings. Despite a reduction in the number of part-time employees in law enforcement activities, the administrative department in charge of these issues was one of the most successful in the Republic of Croatia.

- Through intensive work, the prefect ensured system flexibility and its faster adaptation to the needs of users, while speeding up the process of making decisions on submitted proposals.

- The orderly functioning of administrative bodies of the County is ensured. During the reporting period, the governing bodies carried out the activities within their scope of work in accordance with the adopted acts, and within the set deadlines and the planned funds.

- The system of preventive control and elimination of non-compliance has functioned properly.

- Most of the planned commitments were fulfilled, whereas in addition to the actual realization, customer satisfaction with the service(s) provided was established as performance criterion.

- User satisfaction is a significant indicator of the success of the quality management system. Osijek-Baranya County paid special attention to user satisfaction based on discussions and evaluation of the County Assembly when considering submitted reports and proposals, reports on the implementation of strategic and annual planning documents, the findings of competent supervisory authorities, and submissions made by citizens in writing or through the County web portal. Satisfaction surveys have been actively used since the implementation of the quality management system. The data collected using this new instrument are used for future planning.

- In the period under review, six EU-funded projects run by Osijek-Baranya County were assessed as the most successful local projects implemented in Croatia.

The most important benefits of implementing a QMS are as follows: defining system measurement criteria, monitoring performance and system enhancement, and continually reevaluating environmental goals. Although employees did not always link improvements in the system with ISO standards themselves, improvements were evident. Continuous performance evaluation has become an integral part of the system, continuous audits created the culture of self-assessment, and external audits were used as a basis for improvements.

The QMS has proven to be a successful tool in the hands of public administration. Among other things, performance measurement pursuant to international criteria has helped Osijek-Baranya County create and maintain an image of a reliable partner, both nationally and internationally.

\section{Conclusion}

Public administration in Croatia does not sufficiently monitor the performance of its bodies in terms of expectations and demands of modern administration aimed at service users, especially citizens. With the aim of modernizing public administration, strategic documents envisage the introduction of a quality management system. In the national and international literature, quality management systems have been found to improve performance, the quality of service provided and customer satisfaction. In a constantly changing environment, the administrations implementing quality management systems have a sound basis for self-assessment, control, and 
evaluation of their own performance. The application of the system implies continuous rethinking of one's operation, as well as the tools and methods used to achieve the planned results. By comparing its results with the environment, learning from best practices, developing a reward system and applying other tools and techniques, Croatia can follow the example of countries that have modernized their public administration and make a significant leap forward in doing the same.

Counties are increasingly turning to management systems. Initially (in 2005), only a small number of them were interested in implementing quality management systems, with Istria and Osijek-Baranya counties leading the way. Since then, that number has been constantly growing despite the fact that the ISO 9001 standard has been revised three times. The introduction of the audit process is an improvement in itself, but it requires institutions to continually upgrade their performance.

Although Osijek-Baranya County completed its implementation process in 2011, i.e., six years after the implementation decision was made, all past administrations have recognized the benefits of implementing the system. Despite lagging behind European trends, Osijek-Baranya County was one of the first counties in Croatia to recognize the need for change in public administration, showed the willingness to change and the desire to measure its own performance against international standards.

Thus, it can be concluded that quality management systems improve resource management, as well as the efficiency, timeliness and transparency of public administration procedures. 


\section{REFERENCES}

1. Biškup, I. (2012). Institucionalni uvjeti za unapređenje gospodarskog razvitka županija slučaj Varaždinske županije. Ekonomski pregled, 63(3-4), 786-226.

2. Brito, E., Pais, L., dos Santos, N. R. \& Figueiredo, C. (2020). Knowledge management, customer satisfaction and organizational image discriminating certified from non-certified (ISO 9001) municipalities. International Journal of Quality \& Reliability Management, 37(3), 451-469. https://doi.org/10.1108/IJQRM-10-2018-0281

3. Ćwiklicki, M., Pilch, K. \& Żabiński, M. (2019). ISO 9001 quality management systems in local government institutions in Poland: past, present and future. International Review of Administrative Sciences, 85(2), 207-220. https://doi.org/10.1177/0020852318815280

4. Džinić, J. \& Manojlović, R. (2016). Evaluation of the efficiency in the implementation of quality improvement instruments in Croatian local self-government units-case study. In Koprić, I. et al. (Eds.), Upravljanje kvalitetom i učinkovitošću u lokalnoj samoupravi i javnoj upravi (pp. 39-65). Institut za javnu upravu.

5. Engel, C. (2002). Common Assessment Framework: the state of affairs. Eipascope, 2(1), 1-5.

6. Fazlović, S. \& Kakeš, D. (2015). Unaprjeđenje kvalitete usluga u javnom sektoru Bosne i Hercegovine implementacijom sustava upravljanja kvalitetom. Poslovna izvrsnost: znanstveni časopis za promicanje kulture kvalitete i poslovne izvrsnosti, 9(2), 31-47.

7. Fonseca, L. M. C. M. D., Domingues, J. P., Baylina, P. \& Harder, D. (2019). ISO 9001: 2015 adoption: A multi-country empirical research. Journal of Industrial Engineering and Management, 12(1), 27-50. https://doi.org/10.3926/jiem.2745

8. Hur, M. H. (2009). The influence of total quality management practices on the transformation of how organisations work. Total Quality Management, 20(8), 847-861.

https://doi.org/10.1080/14783360903128306

9. Ivanova, G. N. \& Androsenko, N. Y. V. E. (2014). Application of standardization tools to improve the performance of executive authorities. Economic and Social Changes: Facts, Trends, Forecast, 5(1), 238250. https://doi.org/10.15838/esc/2014.5.35.20

10. Jašarević, S. \& Miličević, Đ. (2016). Kvaliteta u javnoj upravi. In Brdarević, S. \& Lemeš, S. (Eds.), Sistem kvaliteta $i$ organizacione kulture u jedinicama lokalne samouprave (pp. 57-74). Politehnički fakultet Univerziteta u Zenici.

11. Karasoy, H. A. (2018). Quality Management in Turkish Public Management: Challenges and Benefits. European Scientific Journal, 4(5), 11-19. https://doi.org/10.19044/esj.2018.v14n5p11

12. Douglas, E. (2018). Putting a Powerful Tool to Practical Use: The Application of Strategic Planning in the Public Sector. In Kearney, C. R. \& Berman, E. M. (Eds.), Public Sector performance: management, motivation and measurement (pp. 121-133). Routledge. https://doi.org/10.4324/9780429497964-13

13. Kozhevina, O., Yurchenko, E. \& Balunova, N. (2015). Development of management quality assessment methodology in the public sector: Problems and contradictions. Economy of Region, 1(3), 39-52. https://doi.org/10.17059/2015-3-4

14. Mani, B. G. (1995). Old wine in new bottles tastes better: A case study of TQM implementation in the IRS. Public Administration Review, 55(2), 147-158. https://doi.org/10.2307/977180

15. Marimon, F., Melão, N. \& Bastida, R. (2019). Motivations and benefits of quality management systems in social services: mediation of the implementation process. Total Quality Management \& Business Excellence, 32(7-8), 693-718. https://doi.org/10.1080/14783363.2019.1626707

16. Malenica, D., Gruičić, O., Linić, M. \& Čandrlić-Dankoš, I. (2016). Redefiniranje upravljanja dokumentacijom sustava upravljanja kvalitetom jedinica regionalnih samouprava po normi ISO 9001: 2015. In Šimunec, K. (Ed.), LJUDI-temelj uspješnosti sustava upravljanja (p. 56). Poreč: Hrvatsko društvo za kvalitetu. 
17. Matei, A. \& Bălăceanu, E. B. (2014). Performance through the Common Assessment Framework. A critical review for Romania. Procedia-Social and Behavioral Sciences, 143, 862-866. https://doi.org/10.1016/j.sbspro.2014.07.491

18. Moustakis, V. (2014). Total quality management and change management in public organizations. In Sinteza 2014 - Impact of the Internet on Business Activities in Serbia and Worldwide (pp. 38-42). Singidunum University.

19. Nurcahyo, R., Kristiningrum, E. \& Sumaedi, S. (2019). ISO 9001-certified public healthcare center's efficiency and re-certification. International Journal of Productivity and Performance Management, 68(5), 5-15. https://doi.org/10.1108/IJPPM-11-2018-0406

20. Paljaga, M. \& di Rovigno, G. R. C. (2001). Uvođenje Total Quality Managementa u jedinicama lokalne samouprave i organizacijske promjene. RIF, Dodatak časopisu broj 1, 4-25.

21. Peris-Ortiz, M., de la Cruz del Río-Rama, M. \& Álvarez-García, J. (2015). Benefits of Implementing a Quality Management System in Spanish Thalassotherapy Centres in Peris-Ortiz. In Álvarez-García, J. \& Rueda-Armengot, C. (Eds.), Achieving competitive advantage through quality management (pp. 1-16). Springer. https://doi.org/10.1007/978-3-319-17251-4_1

22. Petar, S. (1996). Uvod u upravljanje kvalitetom ISO 9000. Nading.

23. Selen, W. J. \& Schepers, J. (2001). Design of quality service systems in the public sector: Use of quality function deployment in police services. Total Quality Management, 12(5), 677-687. https://doi.org/10.1080/09544120120060141

24. Sisek, B. \& Pavković, Z. (2008). Upravljanje kvalitetom u državnoj upravi. Business Excellence, 2(1), 83-96.

25. Singh, P. J. \& Mansour-Nahra, P. (2006). ISO 9000 in the public sector: a successful case from Australia. The TQM magazine, 68(5), 1988-2007. https://doi.org/10.1108/09544780610647856

26. Staes, P. \& Thijs, N. (2005). Report on the state of affairs of the common assessment framework (CAF) after five years. EIPAScope, 3(1), 41-49.

27. Stringham, S. H. (2004). Does quality management work in the public sector. Public Administration and Management: An Interactive Journal, 9(3), 182-211.

28. Tachiki, D. S. (2010). TQM in the Bangladesh Public Sector: An Action Research Note. Essay Series: Summary of the Faculty of Business Administration, 14(1), 1-11.

29. Van den Berghe, W. (1997). Application of ISO 9000 Standards to Education and Training. Interpretation and Guidelines in a European Perspective. CEDEFOP Document. Bernan Associates.

30. Vujić, T. (2018). Standardizacija rada lokalnih zajednica u funkciji povećanja efikasnosti upravljanja. Sinergija, 19(4), 53-55. https://doi.org/10.7251/ZRSNG1801052V

31. Williams, R., Bertsch, B., Van der Wiele, A., Van Iwaarden, J. \& Dale, B. (2006). Self-assessment against business excellence models: a critique and perspective. Total Quality Management and Business Excellence, 17(10), 1287-1300. https://doi.org/10.1080/14783360600753737 